\title{
PENGARUH ANATOMI STRUKTUR PENDUKUNG GIGI TIRUAN PENUH RAHANG BAWAH TERHADAP RETENSI DAN STABILISASI
}

\author{
Amira Putri Heidira ${ }^{a}$, Eddy Dahar \\ ${ }^{a}$ Mahasiswa Kedokteran Gigi, ${ }^{b}$ Dosen Departemen Prostodonsia \\ Fakultas Kedokteran Gigi \\ Universitas Sumatera Utara, Medan \\ Email: amiraputri29@yahoo.com
}

\begin{abstract}
Complete edentulous is a condition which a person loses all of his or her natural teeth. The treatment is done by making a complete denture (CD). The parameter of successful treatment is dependent on its use. Patient's ability to adapt to new CDs is often becomes the problem. If it's not solved properly, it will impact the oral health and quality of life of the patients, so posttreatment evaluation and control are important. One problem that is widely complained is the retention and stability of lower $\mathrm{CD}$. According to previous studies, the patient's adaptation to $\mathrm{CD}$ is related to the condition of dentures, which is a combination of CD's quality and characteristics of alveolar ridges, so the difference between dentist's evaluation of CD's quality and patient's subjective assessment could happen due to improper clinical assessment of denture-bearing area, which consists of anatomy of supporting and limiting structures. However, other researches suggest alveolar ridges don't affect patient acceptance of CDs, so studies in this area are still considered equivocal. The purpose of this study is to determine the influence of anatomy of lower complete denture supporting structures on retention and stability. This study is a descriptive analytic research with clinical examination of lower denture and oral cavity. Total of samples are $30 \mathrm{CD}$ patients those fulfill the inclusion and exclusion criteria. The result of this study based on the Fisher Exact Test showed a significant influence between the anatomy of lower complete denture supporting structures on retention and stability.
\end{abstract}

Key words: Supporting Structures, Lower Complete Denture, Retention, Stability

\section{PENDAHULUAN}

Kehilangan seluruh gigi atau edentulus penuh adalah suatu keadaan dimana seseorang mengalami kehilangan seluruh gigi aslinya. Kehilangan seluruh gigi sering digunakan sebagai indikator umum untuk menilai kesehatan penduduk serta kecukupan dari sistem perawatan kesehatan gigi dan mulut di suatu negara (Peltzer et al, 2014). Kehilangan gigi dapat disebabkan oleh banyak faktor, namun karies dan penyakit periodontal masih merupakan penyebab utama (Pradeep, 2009). Perawatan pada pasien dengan edentulus penuh dapat dilakukan dengan pembuatan gigi tiruan penuh konvensional. Gigi tiruan penuh (GTP) didefinisikan sebagai suatu protesa yang menggantikan keseluruhan gigigeligi dan jaringan mulut disekitarnya. Tujuan dari gigi tiruan ini adalah untuk merehabilitasi sistem stomatognatik (Goiato, 2011).

Parameter

keberhasilan perawatan GTP sangat tergantung pada pemakaian gigi tiruan tersebut. Satu hal yang sering menjadi permasalahan dalam perawatan GTP adalah kemampuan pasien untuk memakai dan 
beradaptasi terhadap protesa. Hal ini jika tidak teratasi dengan baik maka sebagian besar GTP akan dinilai tidak memuaskan oleh pasien dan berdampak pada kesehatan mulut serta kualitas hidup pasien (Nimri, 2016). Oleh karena itu, evaluasi hasil perawatan serta kontrol setelah pemasangan GTP penting untuk dilakukan. Tujuannya adalah untuk membantu mengatasi masalah dan keluhan pasien terhadap gigi tiruan. Beberapa keluhan yang sering timbul setelah pemasangan GTP adalah adanya kelonggaran, ketidaknyamanan, masalah yang berhubungan dengan retensi dan stabilisasi, serta permasalahan lain seperti kesulitan dalam berbicara dan makan. Salah satu masalah yang paling banyak dikeluhkan oleh pasien adalah masalah pada retensi dan stabilisasi (Lunia, 2017).

Retensi adalah kualitas pada gigi tiruan yang bertindak untuk melawan kekuatan pemindahan sepanjang gigi tiruan ditempatkan, sedangkan stabilisasi didefinisikan sebagai resistensi gigi tiruan terhadap pergerakan pada fondasi jaringannya, terutama terhadap gaya lateral (horizontal) yang berlawanan dengan perpindahan vertical (Ferro, 2017 dan Ribeiro 2014).

Dalam penelitian Baat (1997), adaptasi pasien terhadap GTP sangat berhubungan pada kondisi protesa, yang merupakan kombinasi dari kualitas gigi tiruan dan karakteristik dari linggir sisa alveolar. Sehingga, perbedaan antara evaluasi dokter gigi mengenai kualitas gigi tiruan dan penilaian subjektif pasien dapat disebabkan dari pemeriksaan atau penilaian klinis yang kurang tepat pada kualitas denture-bearing area (Ribeiro, 2014). Menurut Zarb (2004), denture- bearing area terdiri dari anatomi struktur pendukung dan pembatas gigi tiruan. Pada gigi tiruan rahang bawah, anatomi struktur pendukung terdiri dari resiliensi dari puncak linggir alveolar, buccal shelf, dan bentuk dari struktur atau tulang pendukung (Zarb, 2004)

Beberapa penelitian sudah dilakukan untuk mengetahui adanya hubungan linggir alveolar dengan keberhasilan perawatan prostodontik. Pada penelitian Fenlon (2000), terhadap 723 pasien pemakai GTP membuktikan bahwa bentuk dari sisa linggir alveolar memengaruhi kepuasan pasien serta penggunaan gigi tiruan baru. Namun, pada penelitian lain oleh Van Waas (1990) dan Celebic (2003) menyimpulkan bahwa tidak ada hubungan yang signifikan antara denture-bearing area terhadap kepuasan dan penerimaan pasien terhadap gigi tiruan (Ribeiro, 2014 dan Celebic, 2003). Oleh karena itu, studi pada bidang ini masih dianggap samarsamar dan kekurangan metodologi standar untuk perbandingannya (Critchlow, 2010).

\section{METODE PENELITIAN}

Penelitian ini adalah penelitian deskriptif analitik dengan pemeriksaan klinis GTP rahang bawah dan rongga mulut pasien. Penelitian ini dilakukan pada bulan Juni hingga Agustus tahun 2019 di Fakultas Kedokteran Gigi Universitas Sumatera Utara. Populasi dalam penelitian ini adalah pasienpasien yang melakukan perawatan GTP di RSGM USU yang telah menggunakannya selama minimal 6 bulan. Cara sampling yang digunakan adalah teknik penarikan sampel non probabilitas secara purposive sampling. Jumlah sampel adalah 30 orang. Kriteria inklusi dari penelitian ini 
adalah GTP tidak retak, patah, tidak pernah diperbaiki, dan subjek bersedia menandatangani informed consent. Kriteria eksklusi adalah subjek yang melakukan perawatan GTP namun tidak lagi menggunakannya, subjek dengan xerostomia, dan memiliki penyakit sistemik, seperti diabetes mellitus dan osteoporosis, dan subjek yang tidak mau menandatangani informed consent.

Dalam penelitian ini, subjek diminta untuk membuka mulut, lalu peneliti akan memeriksa resiliensi dari puncak linggir alveolar rahang bawah pasien menggunakan ball burnisher (Inspire Instrument SS Germany). Pemeriksaan dilakukan dengan menekankan burnisher pada mukosa diatas prosesus. Jika saat ditekankan burnisher tidak terlalu terbenam, maka jaringan di sekitar puncak linggir dikatakan resilien. Namun, jika mukosa bisa bergerak dalam arah bukolingual saat ditekan menggunakan burnisher, maka berarti jaringan flabby.

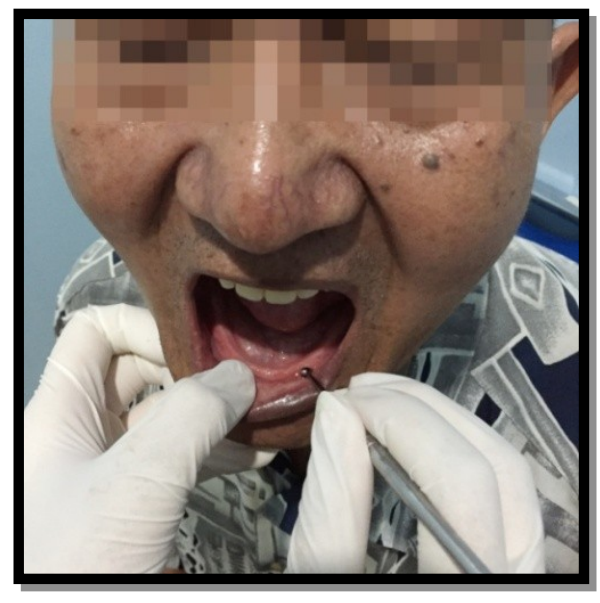

Gambar 1. Pemeriksaan resiliensi puncak linggir alveolar rahang bawah

Peneliti lalu menilai bentuk dari linggir alveolar rahang bawah dengan melakukan pencetakan anatomis dengan menggunakan alginat (Hygedent). Bentuk dari linggir alveolar kemudian diamati dan ditentukan bentuknya berdasarkan klasifikasi menurut Cawood dan Howell (1988). Karena semua subjek sudah edentulus, maka penilaian dimulai dari bentuk linggir edentulus itu sendiri; 1 - well-rounded ridge (klas III), 2 - knife-edge ridge (klas IV), 3 low well-rounded ridge (klas V), dan 4 - depressed ridge (klas VI).

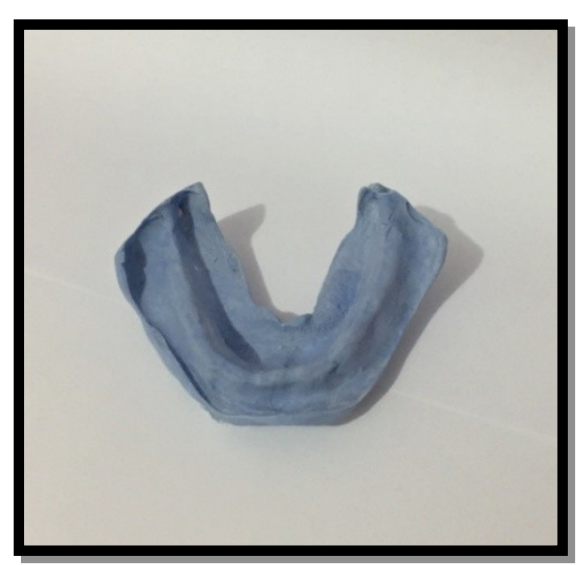

G

GGambar 2. Hasil cetakan dari bentuk linggir alveolar rahang bawah klas III (well-rounded ridge) 
Gambar 3. Hasil cetakan dari bentuk linggir alveolar rahang bawah klas IV (knife-edge ridge)

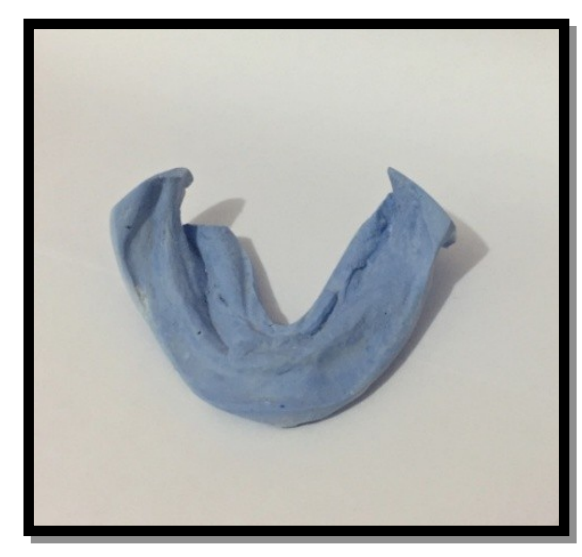

Gambar 4. Hasil cetakan dari bentuk linggir alveolar rahang bawah klas $\mathrm{V}$ (low well-rounded ridge)

Pemeriksaan retensi GTP rahang bawah dilakukan dengan menggunakan push and pull meter. Aplikasikan loop (diameter 0,7 cm) dengan resin akrilik swapolimerisasi dipermukaan mid-lingual pada GTP rahang bawah antara gigi insisivus sentralis. Loop berfungsi sebagai tempat meletakkan kaitan push and pull meter saat pengukuran retensi. Untuk melakukan pemeriksaan, pasien didudukkan dengan posisi tubuh tegak dengan dataran oklusal sejajar dengan permukaan lantai. Lakukan pemasangan tangkai push and pull meter untuk mencapai arah tarikan pada loop yang terdapat pada gigi tiruan rahang bawah. Push and pull meter dipegang dengan telapak tangan lalu tarikan arah vertikal ke atas dilakukan sebagai gaya untuk melepaskan gigi tiruan. Dilakukan penarikan secara vertikal sebesar 2,5 $\mathrm{N}, 5 \mathrm{~N}$, dan $10 \mathrm{~N}$, lalu diamati gaya yang diperlukan untuk melepaskan gigi tiruan dan tentukan skor retensi. Resin akrilik swapolimerisasi dan loop dilepas dengan menggunakan mikromotor dan bur fraser, lalu basis gigi tiruan dipoles kembali agar permukaan basis tidak kasar.

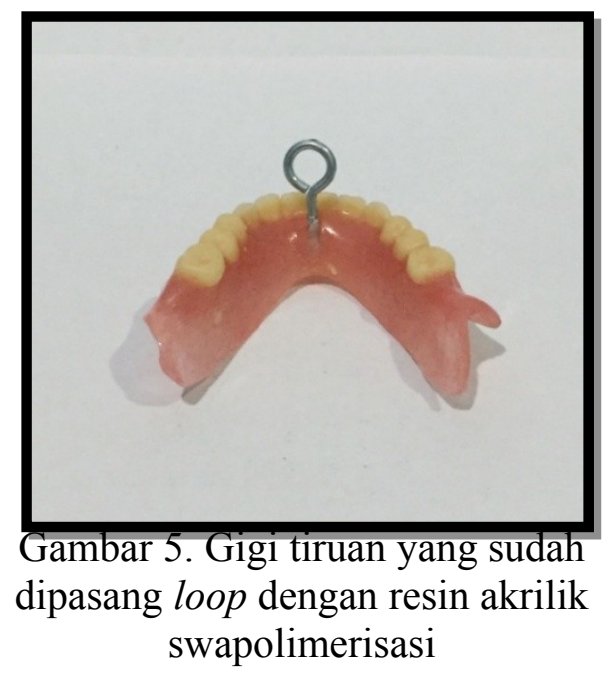




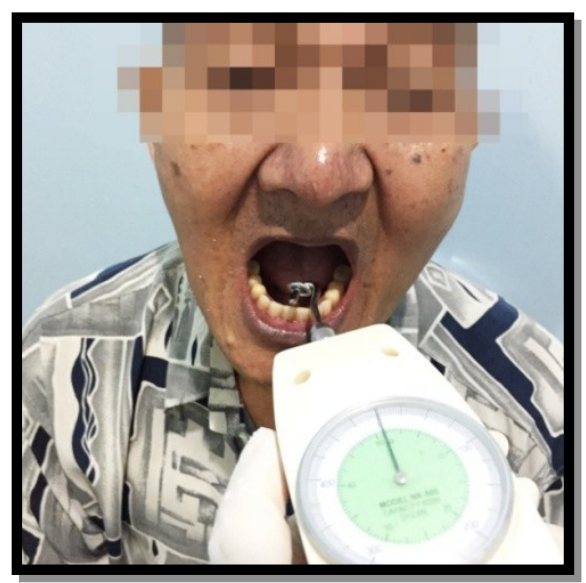

Gambar 6. Pemeriksaan retensi gigi tiruan

\section{dengan push and pull meter}

Penilaian terhadap stabilisasi gigi tiruan rahang bawah dilakukan dengan meletakkan ibu jari dan jari telunjuk pada permukaan bukal dari gigi premolar, kemudian gigi tiruan digerakkan secara horizontal, anteriorposterior, dan mediolateral. Tipping dapat dilihat dengan cara memberikan tekanan pada gigi molar dengan jari telunjuk. Terjadinya pergerakan atau tipping diobservasi dan tentukan skor stabilisasi gigi tiruan. Penilaian stabilisasi GTP kemudian diklasifikasikan mengikuti kriteria berdasarkan CU-modified Kapur (Limpuangthip, 2018).

Tabel 1. Kriteria berdasarkan $C U$ modified Kapur dan skor untuk mengevaluasi retensi dan stabilisasi GTP

\begin{tabular}{|l|l|}
\hline \multicolumn{3}{|c|}{ CU-modified Kapur } \\
\hline Retensi & \multicolumn{1}{|c|}{ Stabilisasi } \\
\hline 3 (baik): resistensi & 2 (baik): tidak ada \\
maksimal, terhadap & pergerakan/terdapat \\
penarikan vertikal & rocking minimal \\
dan gaya lateral & atau pergerakan \\
atau dibutuhkan & horizontal 1-2 mm \\
lebih dari 10 N & \\
untuk GTP terlepas & \\
\hline
\end{tabular}

2 (sedang): 1 (sedang): terdapat resistensi sedang, rocking sedang atau terhadap penarikan pergerakan vertikal dan/atau horizontal 2-4 $\mathrm{mm}$ gaya lateral sebesar 5 N atau dibutuhkan sebesar 5-10 N untuk GTP terlepas 1 (buruk): 0 (buruk): terdapat resistensi minimal, rocking ekstrim yang terhadap penarikan terlihat nyata atau vertikal dan/atau pergerakan gaya lateral sebesar horizontal lebih dari $2,5 \mathrm{~N}$ atau $4 \mathrm{~mm}$ dibutuhkan sebesar 2,5-5 N untuk GTP terlepas

0 (sangat buruk): Terdapat pergerakan saat GTP ditempatkan pada linggir alveolar

Semua data yang diperoleh disajikan dengan melakukan uji statistik dengan SPSS (IBM SPSS 20) menggunakan Chi-Square dan Fisher Exact Test.

\section{HASIL PENELITIAN}

Dalam penelitian ini, anatomi struktur pendukung gigi tiruan penuh rahang bawah terdiri dari resiliensi puncak linggir alveolar dan bentuk linggir alveolar rahang bawah. Terkait dengan retensi GTP rahang bawah, resiliensi puncak liggir alveolar ditemukan resilien sebanyak 7 pasien da $(50 \%)$, yang memiliki retensi gigi tiruan dengan skor 2 atau sedang. Namun, 7 pasien $(43,8 \%)$ dengan puncak linggir alveolar yang flabby juga memiliki penilaian klinis gigi tiruan penuh rahang bawah dengan skor 1 atau buruk (Tabel 2). 
Tabel 2. Distribusi retensi gigi tiruan rahang bawah berdasarkan resiliensi puncak linggir alveolar pada pasien GTP di RSGM USU

\begin{tabular}{|c|c|c|c|c|c|c|c|c|}
\hline \multirow{3}{*}{$\begin{array}{c}\text { Resilie } \\
\text { nsi } \\
\text { Puncak } \\
\text { Linggir } \\
\text { Alveola } \\
\text { r }\end{array}$} & \multicolumn{8}{|c|}{$\begin{array}{c}\text { Retensi Gigi Tiruan Rahang } \\
\text { Bawah } \\
\end{array}$} \\
\hline & \multicolumn{2}{|c|}{ Skor 0} & \multicolumn{2}{|c|}{ Skor 1} & \multicolumn{2}{|c|}{ Skor 2} & \multicolumn{2}{|c|}{ Skor 3} \\
\hline & $n$ & $\%$ & 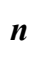 & $\%$ & $n$ & $\%$ & $n$ & $\%$ \\
\hline $\begin{array}{l}\text { Resilie } \\
n\end{array}$ & 0 & 0 & 3 & 3 & 7 & 50 & 4 & $\begin{array}{c}28, \\
6\end{array}$ \\
\hline Flabby & 6 & $\begin{array}{c}37, \\
5\end{array}$ & 7 & $\begin{array}{c}43 \\
8\end{array}$ & 2 & $\begin{array}{c}12 \\
5\end{array}$ & 1 & 6,2 \\
\hline
\end{tabular}

Terkait dengan retensi GTP rahang bawah, bentuk linggir alveolar yang well-rounded ridge (kelas III) ditemukan paling banyak 7 pasien (46,7\%) memiliki retensi sedang. Pada linggir klas IV paling banyak memiliki retensi dengan skor 0 atau sangat buruk $(41,7 \%)$ dan skor 1 atau buruk $(41,7 \%)$ sebanyak 5 orang, sedangkan pada bentuk klas $\mathrm{V}$ memiliki jumlah yang sama pada skor 0 (sangat buruk), 1 (buruk), dan 2 (sedang) yaitu sebanyak 1 orang $(33,3 \%)$ (Tabel 3).

Tabel 3. Distribusi retensi gigi tiruan rahang bawah berdasarkan bentuk linggir alveolar pada pasien GTP di RSGM USU

\begin{tabular}{|c|c|c|c|c|c|c|c|c|}
\hline \multirow{3}{*}{$\begin{array}{c}\text { Bentuk } \\
\text { Linggir } \\
\text { Alveolar }\end{array}$} & \multicolumn{8}{|c|}{$\begin{array}{c}\text { Retensi Gigi Tiruan Rahang } \\
\text { Bawah }\end{array}$} \\
\hline & \multicolumn{2}{|c|}{$\begin{array}{c}\text { Skor } \\
\text { 0 }\end{array}$} & \multicolumn{2}{|c|}{$\begin{array}{c}\text { Skor } \\
1\end{array}$} & \multicolumn{2}{|c|}{$\begin{array}{c}\text { Skor } \\
2\end{array}$} & \multicolumn{2}{|c|}{ Skor 3} \\
\hline & $n$ & $\%$ & $n$ & $\%$ & $n$ & $\%$ & $n$ & $\%$ \\
\hline Klas III & 0 & 0 & 4 & $\begin{array}{c}26, \\
7\end{array}$ & 7 & $\begin{array}{c}46, \\
7\end{array}$ & 4 & $\begin{array}{c}26 \\
7\end{array}$ \\
\hline Klas IV & 5 & $\begin{array}{c}41 \\
7\end{array}$ & 5 & $\begin{array}{c}41, \\
7\end{array}$ & 1 & 8,3 & 1 & 8,3 \\
\hline Klas V & 1 & $\begin{array}{c}33 \\
3\end{array}$ & 1 & $\begin{array}{c}33, \\
3\end{array}$ & 1 & $\begin{array}{c}33 \\
3\end{array}$ & 0 & 0 \\
\hline Klas VI & 0 & 0 & 0 & 0 & 0 & 0 & 0 & 0 \\
\hline
\end{tabular}

Sehubungan dengan stabilisasi GTP rahang bawah, pasien dengan puncak linggir resilien paling banyak memiliki stabilisasi gigi tiruan dengan skor 2 atau baik sebanyak 10 orang $(71,4 \%)$, sedangkan pasien dengan

\begin{tabular}{|l|c|c|c|c|c|c|}
\hline \multirow{2}{*}{$\begin{array}{c}\text { Resliensi } \\
\text { Puncak }\end{array}$} & \multicolumn{4}{|c|}{ Stabilisasi Gigi Tiruan Rahang } \\
\cline { 2 - 7 } $\begin{array}{c}\text { Linggir } \\
\text { Alveolar }\end{array}$ & \multicolumn{2}{|c|}{ Skor 0 } & \multicolumn{2}{|c|}{ Skor 1 } & \multicolumn{2}{|c|}{ Skor 2 } \\
\cline { 2 - 7 } & $\boldsymbol{n}$ & $\boldsymbol{\%}$ & $\boldsymbol{n}$ & $\boldsymbol{\%}$ & $\boldsymbol{n}$ & $\boldsymbol{\%}$ \\
\hline Resilien & 1 & 7,1 & 3 & $\begin{array}{c}21, \\
4\end{array}$ & 10 & 71,4 \\
\hline Flabby & 2 & 12,5 & 8 & 50 & 6 & 37,5 \\
\hline
\end{tabular}

linggir flabby paling banyak memiliki stabilisasi dengan skor 1 atau sedang yaitu sebanyak 8 orang (50\%) (Tabel 4).

Tabel 4. Distribusi stabilisasi gigi tiruan rahang bawah berdasarkan resiliensi puncak linggir alveolar pada pasien GTP di RSGM USU

Sehubungan dengan stabilisasi GTP rahang bawah, bentuk linggir alveolar well-rounded (kelas III) ditemukan sebanyak 13 pasien $(86,7 \%)$ memiliki stabilisasi yang baik atau dengan skor 2. Pasien dengan bentuk linggir knife-edge atau klas IV paling banyak ditemukan memiliki stabilisasi dengan skor 1 atau sedang yaitu sebanyak 7 orang $(58,3 \%)$, sedangkan bentuk linggir klas $\mathrm{V}$ memiliki stabilisasi dengan skor 1 atau sedang $(66,7 \%)$ (Tabel 5).

Tabel 5. Distribusi stabilisai gigi tiruan rahang bawah berdasarkan bentuk linggir alveolar pada pasien GTP di RSGM USU

\begin{tabular}{|c|c|c|c|c|c|c|}
\hline \multirow{2}{*}{$\begin{array}{c}\text { Bentuk } \\
\text { Linggir } \\
\begin{array}{c}\text { Alveola } \\
\mathbf{r}\end{array}\end{array}$} & \multicolumn{2}{|c|}{ Stabilisasi GTP Rahang Bawah } \\
\cline { 2 - 7 } & \multicolumn{2}{|c|}{ Skor 0 } & \multicolumn{2}{|c|}{ Skor 1 } & \multicolumn{2}{c|}{ Skor 2 } \\
\cline { 2 - 7 } & $\boldsymbol{n}$ & $\%$ & $\boldsymbol{n}$ & $\%$ & $\boldsymbol{n}$ & $\%$ \\
\hline Klas III & 0 & 0 & 2 & $\begin{array}{c}13, \\
3\end{array}$ & 13 & $\begin{array}{c}86, \\
7\end{array}$ \\
\hline
\end{tabular}




\begin{tabular}{|l|c|c|c|c|c|c|}
\hline Klas IV & 2 & $\begin{array}{c}16, \\
7\end{array}$ & 7 & $\begin{array}{c}58, \\
3\end{array}$ & 3 & 25 \\
\hline Klas V & 1 & $\begin{array}{c}33, \\
3\end{array}$ & 2 & $\begin{array}{c}66, \\
7\end{array}$ & 0 & 0 \\
\hline Klas VI & 0 & 0 & 0 & 0 & 0 & 0 \\
\hline
\end{tabular}

Analisis data dengan Fisher Exact menunjukkan adanya pengaruh resiliensi puncak linggir alveolar terhadap retensi gigi tiruan dengan $\mathrm{p}=$ $0,005(\mathrm{p}<0,05)$, namun tidak ditemukan pengaruh yang signifikan antara puncak linggir alveolar rahang bawah terhadap stabilisasi gigi tiruan, yaitu dengan $p=0,217(p>0,05)$. Pada bentuk linggir alveolar rahang bawah ditemukan pengaruh yang signifikan terhadap retensi dengan $\mathrm{p}=0,023(\mathrm{p}<$ $0,05)$ dan stabilisasi dengan $p=0,001$ $(\mathrm{p}<0,05)$ (Tabel 6).

Tabel 6. Pengaruh anatomi struktur pendukung gigi tiruan penuh rahang bawah terhadap retensi dan stabilisasi

\begin{tabular}{|c|c|c|}
\hline $\begin{array}{c}\text { Anatomi Struktur } \\
\text { Pendukung Gigi } \\
\text { Tiruan Penuh } \\
\text { Rahang Bawah }\end{array}$ & $\begin{array}{c}\text { Retensi dan } \\
\text { Stabilisasi } \\
\text { Gigi Tiruan } \\
\text { Penuh } \\
\text { Rahang } \\
\text { Bawah }\end{array}$ & p \\
\hline $\begin{array}{c}\text { Resiliensi Puncak } \\
\text { Linggir Alveolar }\end{array}$ & Retensi & $\begin{array}{c}0,005 \\
*\end{array}$ \\
\hline $\begin{array}{c}\text { Bentuk Linggir } \\
\text { Alveolar }\end{array}$ & Retensi & $\begin{array}{c}0,023 \\
*\end{array}$ \\
\hline $\begin{array}{c}\text { Resiliensi Puncak } \\
\text { Linggir Alveolar }\end{array}$ & Stabilisasi & 0,217 \\
\hline $\begin{array}{c}\text { Bentuk Linggir } \\
\text { Alveolar }\end{array}$ & Stabilisasi & 0,001 \\
$*$
\end{tabular}

\section{PEMBAHASAN}

Hasil dari penelitian ini menunjukkan adanya pengaruh yang signifikan pada anatomi struktur pendukung gigi tiruan penuh rahang bawah, yaitu pada resiliensi puncak resiliensi puncak linggir alveolar terhadap retensi dan bentuk linggir alveolar terhadap retensi dan stabilisasi.

Tabel 6 menunjukkan bahwa ada pengaruh yang signifikan antara resiliensi puncak linggir alveolar terhadap retensi dengan nilai $\mathrm{p}=0,005$ ( $p<0,05)$. Hasil ini sesuai dengan penelitian sebelumnya oleh Ribeiro dkk. (2014) yang menyatakan bahwa resilensi puncak linggir alveolar mempengaruhi hasil perawatan GTP, terutama retensi. Hal ini juga didukung oleh Baat (1997) yang menyatakan bahwa keberhasilan perawatan prostodontik tergantung pada kualitas gigi tiruan dan juga kondisi rongga mulut pasien, sehingga dapat disimpulkan bahwa ketika penilaian kualitas gigi tiruan yang cukup buruk, hal ini dapat disebabkan oleh kondisi dari linggir alveolar sisa (Ribeiro, 2014). Selain itu, Pai (2014) menyatakan bahwa linggir flabby dapat menyebabkan GTP bergeser dibawah

kekuatan oklusal dan mengakibatkan hilangnya peripheral seal antara GTP dan jaringan sehingga akan 005 menyebabkan retensi yang buruk (Pai, 2014). Hal ini juga didukung oleh pernyataan Carlsson (1998), bahwa linggir alveolar yang flabby dapat menyebabkan retensi GTP yang buruk (Chiplunkar, 2018). Puncak linggir yang flabby dapat bergerak dengan mudah dan melekat longgar pada tulang periostium. Puncak linggir alveolar yang flabby sering menghadirkan kesulitan dalam pembuatan GTP. Jaringan lunak yang tergeser selama proses pencetakan cenderung kembali ke bentuk aslinya. GTP yang dibuat menggunakan hasil cetakan ini tidak akan pas secara akurat saat jaringan kembali ke bentuk 
aslinya. Hal tersebut dapat mengakibatkan GTP menjadi kurang retentif (Prasad, 2014).

Namun, hasil yang berbeda ditemukan pada penelitian Celebic dkk. (2003) mengenai faktor-faktor yang berhubungan dengan kepuasan GTP. Penelitian ini menunjukkan bahwa pasien dengan kualitas denture-bearing area yang baik memberikan skor rendah untuk retensi dan kenyamanan GTP rahang bawah mereka. Hal ini dapat terjadi karena periode adaptasi neuromuskuler yang lebih lama bagi GTP rahang bawah dan lamanya waktu yang dibutuhkan untuk otot bibir, pipi, dan lidah yang ada disekitar gigi tiruan untuk menyesuaikan fungsinya dengan sayap GTP. Selain itu, ditambah dengan proses resorpsi linggir alveolar, gigi tiruan rahang bawah akan bergerak di bawah kekuatan oklusal dan melukai mukosa mulut, sehingga nantinya akan menyebabkan ketidaknyamanan dan retensi yang buruk dari GTP rahang bawah (Celebic, 2003).

Selain itu, pada tabel 6 juga menunjukkan bahwa ada pengaruh yang signifikan antara bentuk linggir alveolar rahang bawah terhadap retensi dengan nilai $\mathrm{p}=0,023(\mathrm{p}<0,05)$. Hasil ini sesuai dengan penelitian sebelumnya oleh Pridana (2016) yang menyatakan bahwa bentuk tulang alevolus akan mempengaruhi retensi GTP. Setelah pencabutan gigi, tulang alveolar akan mengalami resorpsi yang menyebabkan perubahan bentuk tulang. Bentuk tulang atau linggir alveolar dapat memberikan dukungan bagi GTP karena kemampuannya menahan gaya vertikal dan lateral. Namun, resorpsi tulang alveolar akan menyebabkan pengurangan ukuran tulang sehingga luas dari denture-bearing area menjadi lebih sempit. Luas permukaan denture- bearing area memiliki korelasi positif dengan faktor retensi GTP, yaitu berupa adhesi, kohesi, tegangan permukaan, dan tekanan atmosfer (Pridana, 2016). Bentuk linggir dengan tinggi yang adekuat dan memiliki dinding paralel lebar baik bagi retensi. Retensi juga dipengaruhi oleh kontur aspek lateral dari linggir alveolar (Misch, 2015). Hal ini dapat dilihat dari hasil penelitian dimana 83,4\% subjek dengan linggir knife-edge dan $66,6 \%$ subjek dengan linggir low well-rounded memiliki retensi minimal. Selain itu, setiap prosedur dalam pembuatan GTP juga harus dilakukan dengan baik. Beberapa hal yang menyebabkan GTP menjadi kurang retentif adalah pencetakan yang kurang akurat, hubungan rahang tidak adekuat, dan penyusunan anasir gigi tiruan yang tidak memperhatikan zona netral (Kuntjoro, 2010).

Tabel 6 menunjukkan bahwa tidak ada pengaruh yang signifikan antara resiliensi puncak linggir alveolar terhadap stabilisasi dengan nilai $\mathrm{p}=$ $0,217$ ( $\mathrm{p}>0,05)$. Hasil ini sesuai dengan penelitian Ribeiro dkk. (2014) yang menyatakan bahwa resiliensi puncak linggir tidak berpengaruh pada stabilisasi gigi tiruan rahang bawah. Menurut Ribeiro dkk. (2014) puncak linggir memiliki peran yang lebih besar dalam mencegah perpindahan di bawah gaya vertikal, bukan gaya rotasi (Ribeiro, 2014). Namun, hasil penelitian ini berbeda dari studi sebelumnya yang menyatakan bahwa linggir yang flabby dapat menyebabkan ketidakstabilan GTP. Perawatan pasien dengan linggir yang flabby akan menyebabkan beberapa masalah jika tidak dilakukan dengan teknik pencetakan khusus (Labban, 2018).

Selain itu, hasil penelitian juga menunjukkan adanya pengaruh yang 
signifikan antara bentuk linggir alveolar rahang bawah terhadap stabilisasi dengan nilai $\mathrm{p}=0,001(\mathrm{p}$ $<0,05)$. Hasil penelitian ini didukung oleh penelitian sebelumnya oleh Fenlon (2008) yang menemukan pengaruh yang kuat antara bentuk linggir dan stabilisasi gigi tiruan rahang bawah (Ribeiro, 2014). Bentuk linggir alveolar terbaik adalah berbentuk U atau klas III karena bentuk ini memiliki tinggi yang adekuat sehingga mampu menahan gaya lateral. Hal ini juga sesuai dengan hasil penelitian dimana $70,6 \%$ pasien dengan linggir klas III memiliki stabilisasi GTP yang baik. Selain itu, linggir bentuk $U$ juga memiliki dinding lateral yang dapat menahan kekuatan melepaskan dari arah vertikal. Sebaliknya, bentuk klas V atau IV memiliki sedikit kemampuan untuk menahan kekuatan pelepasan gaya vertikal karena peripheral seal terbuka disegala sisi terus-menerus (Pridana, 2016). Bentuk linggir klas V dengan atropi parah cenderung membuat GTP tidak stabil (Prasad, 2014). Dalam studinya, Zarb dkk. (2005) menyatakan bahwa bentuk tulang yang ideal untuk mendukung GTP adalah sedikit persegi di daerah labial, bukal, lingual dan ditutupi oleh perlekatan mukosa yang baik. Tinggi tulang alveolus juga dapat menahan pergerakan gigi tiruan dengan membatasi ruang gaya yang melepaskan dan dinding lateral tulang yang tertutupi oleh basis gigi tiruan dapat menahan gerakan lateral serta membentuk peripheral seal.

\section{Penelitian} sebelumnya menyatakan bahwa bentuk linggir alveolar dan resiliensi puncak linggir alveolar akan mempengaruhi retensi dan stabilisasi GTP. Namun, dalam penelitian ini, resiliensi puncak linggir alveolar hanya mempengaruhi retensi, tidak mempengaruhi stabilisasi. Sebaliknya, bentuk linggir alveolar memengaruhi retensi dan stabilisasi GTP rahang bawah. Hal tersebut dapat terjadi karena adanya faktor dan kriteria-kriteria yang berbeda pada pemeriksaan dalam beberapa penelitian, baik terhadap anatomi struktur pendukung gigi tiruan maupun retensi dan stabilisasi GTP. Pada penelitian ini masih terdapat beberapa kekurangan. Penilaian terhadap resiliensi puncak linggir alveolar dan bentuk linggir alveolar rahang bawah hanya dilakukan secara umum. Penilaian tidak dilakukan secara spesifik dengan pembagian antara regio anterior dan posterior rahang bawah.

\section{KESIMPULAN}

Terdapat pengaruh anatomi dari struktur pendukung gigi tiruan penuh rahang bawah terhadap retensi dan stabilisasi, yaitu resiliensi puncak linggir alveolar rahang bawah terhadap retensi, dan bentuk linggir alveolar rahang bawah terhadap retensi dan stabilisasi gigi tiruan penuh rahang bawah.

\section{DAFTAR PUSTAKA}

Peltzer K, Hewlett S, Yawson AE. Prevalence of Loss of All Teeth (Edentulism) and Associated Factors in Older Adults in China, Ghana, India, Mexico, Russia and South Africa. Int J Environ Res Public Health 2014; 11: 1130811324.

Pradeep S, Kuriakose S. Causes and Patterns of Loss of Permanent Teeth among Patients Attending a Dental Teaching Institution in South India. 
J Contemp Dent Pract. 2009 Sep 1; 10(5): 1-11.

Goiato MC. Insertion and follow-up of complete dentures: a literature review. Gerodontol. 2011; 28: 197204.

Nimri GEM, Jebreen SE. Oral condition, treatment needs and demands of geriatric "Denture Wearers" in three different Jordanian communities. JRSM. Sep 2016; 23(3): 40-48.

Lunia MR, Nooji D. Post Insertion and Management in Complete Denture Patients. Republic of Moldova: LAP Lambert Academic Publishing; 2017. p 46-73.

Ferro KJ. The Glossary Of Prosthodontic Terms Ninth Edition. J Prosthet Dent. 2017 May; 117(5S): e1-e105.

Ribeiro JAM, Resende CM, Lopes ALC. The influence of mandibular ridge anatomy on treatment outcome with conventional complete dentures. Acta Odontol Latinoam. 2014; 27(2): 53-57.

Zarb GA. Prosthodontic Treatment for Edentulous Patients: Complete Dentures and Implant-Supported Prostheses. India: Mosby. 2004. 211-233.

Critchlow SB, Ellis JS. Prognostic indicators for conventional complete denture therapy: A review of the literature. Journal of Dentistry. 2010; 38: 2-9.

Celebic A. Factors related to patient satisfaction with complete denture therapy. J Gerontol. 2003; 58(10): 948-53.

Limpuangthip N, Somkotra T, Arksomnukit M. Modified retention and stability criteria for complete denture wearers: A risk assessment tool for impaired masticatory ability and oral health-related quality of life. J Prosthet Dent. July 2018; 120(1): 43-49.

Pai UY, Reddy VS, Hosi RN. A Single Step Impression Technique of Flabby Ridges Using Monophase Polyvinylsiloxane Material: A Case Report. 2017 April; 2014: 1-6.

Chiplunkar J, Tumbil M, Chethan MD, Nandeeshwar DB, Patel D. Manage ment of flabby ridge case: An arduo us task in undergraduate practice. Int J Oral Health Sci 2018; 8: 104-8. Prasad K, Mehra D, Prasad A. Prosthodontic Management of Compromised Ridges and Situations. NUJHS 2014 Mar; 4(1): 141-148.

Pridana S, Nasution ID. Bentuk Residual Ridge dan Hubungannya Dengan Retensi Gigi Tiruan Penuh. Cakradonya Dent J 2016; 8(1):1-76.

Misch CE. Dental Implant Prosthetic, 2nd Ed. Missouri: Elsevier. 2015; 942.

Kuntjoro M, Rostiny, Widajati W. Alveolar ridge rehabilitation to increase full denture retention and stability. Dent. J (Maj. Ked. Gigi) 2010; (43)4: 181-185.

Labban N. Management of the flabby ridge using a modified window technique and polyvinylsiloxane impression material. Saudi Dent J 2018; 30: 89. 